\title{
Karakteristik Permukiman Kota yang Memiliki Potensi Usaha Berbasis Rumah Tangga
}

\author{
Ima Rahmawati Sushanti ${ }^{1,2}$, Intan Savia Fitri ${ }^{2}$, Febrita Susanti ${ }^{2}$ \\ ${ }^{1}$ Arsitektur, Fakultas Teknik Sipil Perencanaan dan Kebumian, Institut Teknologi Sepuluh Nopember, Surabaya \\ Kampus ITS Keputih, Sukolilo, Kota Surabaya, Jawa Timur, Indonesia \\ ${ }^{2}$ Perencanaan Wilayah dan Kota, Fakultas Teknik, Universitas Muhammadiyah Mataram, Mataram \\ Jalan KH Ahmad Dahlan No 1 Pagesangan, Kota Mataram, Nusa Tenggara Barat, Indonesia \\ Email: imarahmawati77@gmail.com
}

\begin{abstract}
Abstrak
Permukiman kota merupakan lingkungan binaan di perkotaan yang ikut andil dalam menentukan struktur dan identitas kota. Kawasan permukiman kota saat ini tidak hanya digunakan sebagai tempat tinggal yang dilengkapi sarana dan prasarana untuk memenuhi kebutuhan hidup warga yang tinggal di dalamnya, tetapi juga memenuhi kebutuhan perekonomian mereka. Permukiman kota memiliki karakteristik tertentu berdasarkan masyarakat dan aktivitas di dalamnya sehingga bisa menjadi identitas kawasan. Keberadaan klaster industri Mutiara, Emas dan Perak di kecamatan Sekabela, kota Mataram memberikan implikasi terhadap permukiman sekitarnya, baik pada aspek ekonomi, lingkungan dan sosial. Munculnya permukiman kumuh pada hunian sekitar industri Mutiara, Emas dan Perak menyebabkan kurang optimalnya representasi kawasan sebagai kawasan pariwisata belanja. Penelitian ini bertujuan untuk mengetahui karakteristik permukiman dengan potensi usaha berbasis rumah tangga dan strategi pengembangannya. Metode yang digunakan dalam penelitian adalah deskriptif kualitatif dengan pengumpulan data primer dan sekunder serta analisis Strength, Weakness, Opportunity dan Threat. Hasil penelitian menunjukan bahwa karakteristik permukiman berdasarkan karakteristik fisik, yaitu: tata bangunan, hunian, sarana dan prasarana serta lingkungan dan karaktersitik non fisik, yaitu: masyarakat serta aktivitas yang berlangsung di dalamnya. Strategi pengembangan kawasan berdasarkan karakteristik permukiman berada pada kuadran IV yaitu Competitive Strategy. Upaya yang dilakukan adalah meningkatan kualitas visual atau citra kawasan, melakukan diversifikasi usaha dan mengembangkan pasar
\end{abstract}

Kata kunci: Karakteristik, Kawasan Pariwisata Belanja, Permukiman Kota, Potensi Usaha Berbasis Rumah Tangga, Strategi Kompetitif.

\begin{abstract}
Urban settlement is a built environment in an urban area that plays a role in determining the structure and identity of the city. The urban settlement area is currently not only used as a residence equipped with facilities and infrastructure to meet the living needs of the residents who live in it, but also to meet their economic needs. Urban settlements have certain characteristics based on the community and activities in them so that they can become the identity of the area. The existence of the Mutiara, Gold and Silver industrial clusters in Sekabela sub-district, Mataram city has implications for the surrounding settlements, both in economic, environmental and social aspects. The emergence of slum settlements in the residences around the Pearl, Gold and Silver industry causes less optimal representation of the area as a shopping tourism area. This study aims to determine the characteristics of settlements with household-based business potential and development strategies. The method used in this research is descriptive qualitative with primary and secondary data collection and analysis of Strength, Weakness, Opportunity and Threat. The results showed that the characteristics of the settlement were based on physical characteristics, namely: building layout, housing, facilities and infrastructure as well as the environment and non-physical characteristics, namely: the community and the activities that took place in it. The area development strategy based on settlement characteristics is in quadrant IV, namely the Competitive Strategy. Efforts are being made to improve the visual quality or image of the area, diversify the business and develop markets.
\end{abstract}

Keywords: Characteristics, Tourism Shopping Area, Urban Settlements, Household-Based Business Potential, Competitive Strategy.

\section{Pendahuluan}

Sebagai kota yang memiliki banyak potensi wisata dan dengan karakter permukiman yang beragam, Kota Mataram merupakan salah satu kota dapat menjadi alternatif pengembangan kawasan yang dapat mengangkat potensi asli daerah untuk keuntungan semua pihak. Keberadaan klaster industri di Kota Mataram memberikan pengaruh terhadap kawasan permukiman sekitarnya (Sushanti, 2015). 
Sesuai Rencana Tata Ruang Wilayah (RTRW) Kota Mataram tahun 2011-2031 Kecamatan Sekarbela ditetapkan sebagai pengembangan kawasan perumahan sedangkan Kelurahan Karang Pule, yang merupakan salah satu kelurahan yang ada di Kecamatan Sekarbela ditetapkan sebagai kawasan pariwisata belanja. Industri Mutiara, Emas dan Perak (MEP) yang ada di Kelurahan Karang Pule, Kecamatan Sekarbela, Kota Mataram memiliki jumlah tenaga kerja sekitar 3-4 orang karyawan sehingga dikategorikan sebagai Usaha Berbasis Rumah Tangga (Household-Based Business)

Keberadaan klaster industri MEP memberikan implikasi terhadap permukiman sekitarnya, baik pada aspek ekonomi, lingkungan dan sosial (Sushanti \& Fitri, 2017). Salah satu aspek yang menjadi perhatian dalam hal ini adalah aspek lingkungan. Pada aspek lingkungan terjadinya perubahan terhadap kondisi bangunan, kualitas hunian masyarakat, munculnya permukiman kumuh, perubahan sarana dan prasarana serta adanya pencemaran lingkungan. Munculnya permukiman kumuh pada hunian sekitar industri MEP menyebabkan kurang optimalnya representasi kawasan tersebut dalam mendukung fungsi kawasan sebagai kawasan pariwisata belanja.

Doxiadis (1974) menyatakan bahwa permukiman adalah penataan kawasan yang dibuat oleh manusia yang tujuannya untuk mempertahankan hidup secara lebih mudah dan lebih aman, dan mengandung kesempatan untuk pembangunan manusia seutuhnya. Lima elemen dasar pemukiman: Nature (alam), adalah lahan yang dapat dimanfaatkan untuk membangun tempat tinggal maupun fungsi lainnya; Man (manusia), baik pribadi maupun kelompok yang membangun atau bertempat tinggal; Society (masyarakat), dimana didalamnya terdapat interaksi dan hubungan sosial antar manusia sehingga membentuk ikatan tertentu sebagai masyarakat; Shells (rumah), yakni bangunan tempat tinggal manusia dengan fungsi masing-masing; Networks (jaringan), dengan kata lain sarana prasarana yang mendukung fungsi lingkungan baik alami maupun buatan manusia (Doxiadis, 1968).

Elemen dasar tersebut dapat dijabarkan sebagai berikut : 1) Alam (iklim, kekayaan alam, topografi, ketersediaan air, tempat tanaman bertumbuh dan hewan hidup); 2) Manusia (kebutuhan biologi seperti udara, air, suhu, ruang dan lain sebagainya, kebutuhan emosi seperti hubungan manusia, rasa aman, keindahan dan lain sebagainya, nilai moral dan budaya; 3) Masyarakat (kepadatan penduduk, tingkat strata, budaya, ekonomi, pendidikan kesehatan, hiburan, hukum); 4) Bangunan (rumah, fasilitas umum, perkantoran, tempat rekreasi, industri, transportasi); dan 5) Sarana prasarana (jaringan seperti sistem air bersih, listrik, jalan, telepon, televisi, sarana transportasi, drainase, sampah, MCK). Persebaran permukiman bersifat menentukan terhadap keanekaan pola permukiman. Persebaran- dari aspek aspek kepadatan bervariasi (jumlah luas permukiman dibagi jumlah luas wilayah dimana permukiman itu berada) dari sangat jarang hingga padat. Hudson (1970) membedakan pola permukiman terdiri dari: 1) pola permukiman mengelompok, yaitu pola permukiman yang terbentuk karena rumahrumah penduduk mengelompok di suatu lokasi tertentu. Lokasi pengelompokan biasanya terbentuk di persimpangan jalan, sekitar sumber mata air, muara sungai, atau mengelilingi suatu fasilitas. Pola permukiman mengelompok dapat berkembang ke segala arah tanpa direncanakan. 2) pola permukiman menyebar, yaitu pola permukiman yang terbentuk karena rumah-rumah penduduk dibangun bebas dan tersebar pada suatu wilayah. Pola ini umumnya terdapat di dataran rendah. Dikarenakan dataran rendah memiliki jenis tanah subur sehingga penduduk bebas membangun rumah di wilayah yang dikehendaki.

Usaha berbasis rumah tangga termasuk dalam industri rumah tangga (home industry) dan industri kecil sebagai sistem domestik atau tahap kerajinan rumah. Para pekerja bekerja di rumah masing-masing dengan alat yang dimiliki sendiri. Menurut Siahaan (1996) usaha berbasis industri rumah tangga menggunakan tenaga kerja kurang dari empat orang yang terdiri dari pemilik beserta anggota keluarganya, dengan penggunaan modal yang sangat terbatas. Industri rumah tangga memberikan sumbangan yang cukup besar terhadap pemanfaatan sumber daya manusia, yaitu memberikan peluang kerja dalam upaya mengurangi pengangguran. Tipple dan Kellet (2002) menunjukkan bahwa ruang ditentukan oleh kegiatan yang terjadi di dalam dan bahwa ruang merupakan produk dari terjemahan sosial, transformasi dan pengalaman. Sebagai konsekuensinya, ruang di setiap rumah akan bervariasi sesuai dengan budaya dan kebiasaan penghuninya. Dalam perjalanan waktu, situasi ekonomi pengguna ruang harus dimasukkan sebagai pertimbangan yang tepat selain latar belakang budaya pengguna.

Selain sebagai tempat tinggal, rumah saat ini juga berkembang ke arah fungsi produktif. Menurut Johan Silas (1993) konsep rumah dan kerja termasuk dimensi sosial dan budaya, dapat diuraikan sebagai berikut: 1) Rumah (saja), yaitu rumah yang digunakan sebagai tempat tinggal tanpa kegiatan lain yang berarti, 2) Rumah Produktif, yaitu rumah yang sebagian digunakan untuk produktif atau kegiatan ekonomi, konsekuensinya juga timbul hubungan antara aspek produksi dan perawatan rumah.

Berdasarkan teori tersebut maka perlu dilakukan identifikasi terhadap karakteristik permukiman pada suatu kawasan dengan melihat karakteristik fisik dan non fisik, yaitu: tata bangunan dan lingkungan, sarana dan prasarana, lingkungan, penghuni/ masyarakat, dan aktivitas yang beralangsung serta strategi pengembangan sesuai karakteristik 
permukiman, baik fisik mupun non fisik. Dengan mengetahui karakteristik permukiman yang memiliki potensi usaha permukiman berbasis rumah tangga maka dalam upaya pengembangan yang dilakukan dapat lebih tepat sesuai dengan kondisi dan potensi yang dimiliki. Oleh karena itu, penelitian ini bertujuan untuk melihat sejauh mana karakteristik permukiman dengan potensi usaha berbasis rumah tangga Mutiara, Emas dan Perak (MEP) dan hunian sekitarnya serta upaya pengembangan yang dapat dilakukan dengan segala potensi yang dimiliki termasuk mengatasi permasalahan yang ada di dalamnya sehingga dapat meningkatkan kualitas visual kawasan dan kualitas hidup masyarakat.

\section{Metode Penelitian}

Paradigma penelitian yang digunakan adalah naturalistik dengan strategi penelitian kualitatif. Metode yang digunakan dalam penelitian ini adalah deskriptif dengan pendekatan studi kasus dengan pengumpulan data primer melalui observasi, wawancara terstruktur (kuesioner), wawancara semi terstruktur (pertanyaan substantif), dan dokumentasi serta data sekunder melalui jurnal, buku dan dokumen dari instansi terkait. Metode penelitian dengan rumusan masalah deskriptif yang diangkat memandu peneliti untuk mengeksplorasi dan atau memotret situasi sosial yang akan diteliti secara menyeluruh, luas dan mendalam (Sugiyono, 2015).

Lokasi studi dari penelitian ini berada di 4 (empat) lingkungan dari 7 (tujuh) lingkungan yang ada Kelurahan Karang Pule, Kecamatan Sekarbela, Kota Mataram yaitu di lingkungan Pande Besi, Pande Mas Barat, Pande Mas Timur dan Mas Mutiara. Partisipan yang terlibat dalam penelitian ini adalah 1) mewakili kelompok usaha berbasis rumah tangga, yang terdiri dari pengerajin, penjual dan pengerajin sekaligus penjual, 2) mewakili kelompok non usaha berbasis rumah tangga, yang terdiri dari warga sekitar non usaha berbasis rumah tangga, tokoh masyarakat, dan komunitas, 3) mewakili pemerintah, yaitu aparat kelurahan setempat. Teknik pengumpulan data dilakukan dengan 1) Interaktif (Wawancara dan Diskusi), 2) Identifikasi, 3) Observasi, 4) Deskriptif dan 5) Dokumentasi Analisis yang digunakan adalah analisis SWOT dengan memperhatikan aspek External Faktor Analisis Summary (EFAS) dan Internal Factor Analisis Summary (IFAS).

\section{Hasil dan Pembahasan}

Karakteristik permukiman dengan potensi usaha berbasis rumah tangga dapat diidentifikasi berdasarkan aspek fisik dan non fisik yang berada di kawasan tersebut. Aspek fisik dengan memperhatikan kondisi dan potensi tata bangunan (hunian dan usaha berbasis rumah tangga), sarana dan prasarana serta lingkungan dan karakteristik non fisik, yaitu: masyarakat serta aktivitas yang berlangsung di dalamnya.

\section{Karakteristik Fisik Kawasan}

Karakteristik fisik kawasan permukiman diidenfikasi dengan melihat persebaran bangunan, sarana dan prasarana serta lingkungan.

\section{a. Tata Bangunan (Hunian dan Usaha Berbasis Rumah Tangga)}

Hunian yang berada di sekitar usaha berbasis rumah tangga MEP di Kelurahan Karang Pule, Kecamatan Sekarbela, Kota Mataram memiliki pola yang tidak teratur dan grid. Sehingga termasuk kategori pola menyebar dan mengelompok. Pola menyebar dapat dilihat dari persebaran permukiman yang memiliki jarak yang cukup jauh antara rumah yang satu dengan rumah yang lain, sedangkan pola mengelompok, dapat dilihat dari penumpukan permukiman yang secara tidak teratur bertumpuk di masing-masing lingkungan. Hal tersebut dapat dilihat pada Gambar 1 berikut:

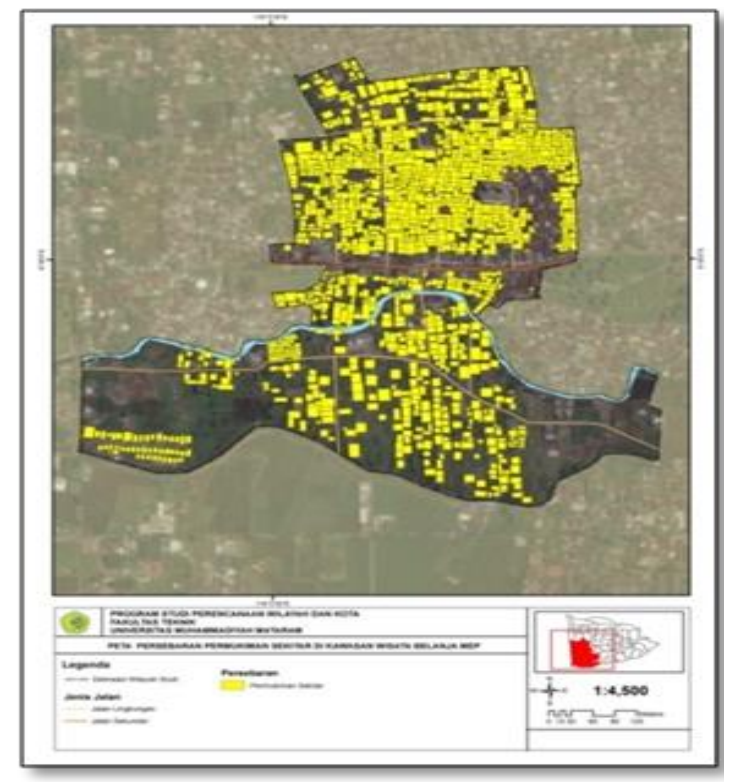

Gambar 1. Peta Persebaran Hunian

Hunian di kawasan permukiman MEP sudah didominasi oleh bangunan permanen yang termasuk dalam kondisi cukup layak dan layak. Bangunan rumah antara satu warga dengan warga lainnya hampir tidak mempunyai jarak. Tidak jarang ditemukan tembok rumah sebagai pemisah antara satu rumah dengan rumah lainnya. Selain itu akses jalan juga sangat sempit, hanya dapat dilewati oleh dua kendaraan bermotor. Jarak kepadatan bangunan ini terhitung tinggi, sehingga aspek aksesibilitas dan mobilitas dianggap rendah. Hal tersebut dapat dilihat pada Gambar 2 berikut: 


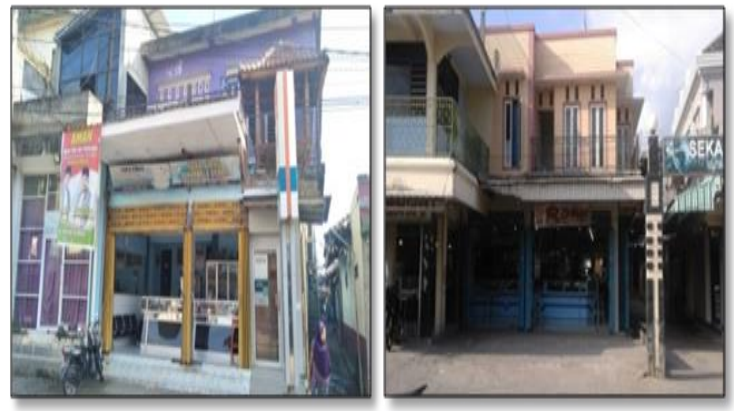

Gambar 2. Kondisi hunian dan Usaha Berbasis Rumah Tangga yang layak

Kondisi hunian yang ada pada hunian sekitar home industry MEP di Kelurahan Karang Pule, Kecamatan Sekarbela, Kota Mataram sebagian besar sudah didominasi oleh bangunan permanen yang termasuk dalam kondisi yang layak. Namun, masih terdapat beberapa hunian yang masih dalam kondisi yang tidak layak. Hal tersebut dapat dilihat pada gambar 3 berikut:
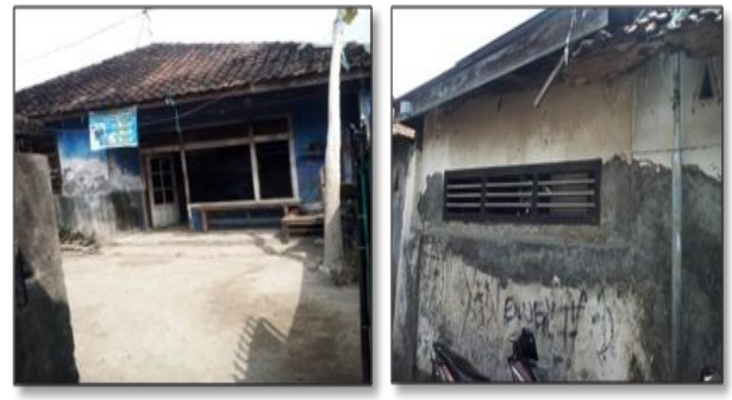

Gambar 3. Kondisi hunian sekitar usaha berbasis rumah tangga yang layak

Persebaran usaha berbasis rumah tangga terbagi menjadi 3 (tiga) kelompok yaitu pengerajin, pengerajin yang juga merupakan penjual, penjual (pedagang). memiliki pola mengelompok atau klaster yang berada di masing-masing lingkungan. Hal tersebut dapat dilihat pada gambar 4 berikut:

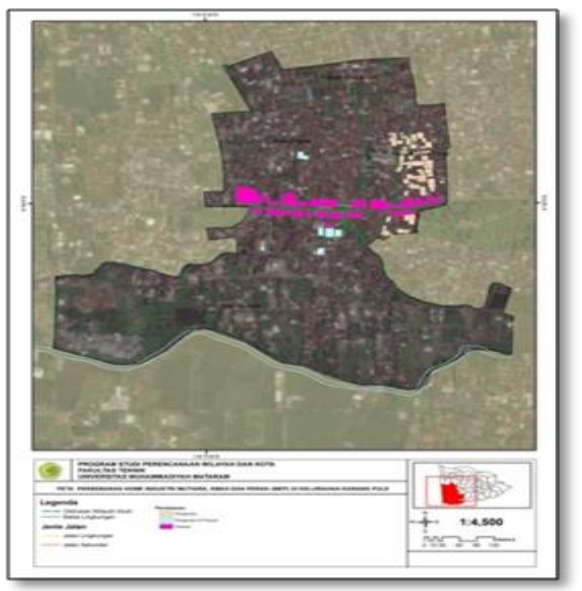

Gambar 4. Peta Persebaran Usaha Berbasis Rumah Tangga

\section{b. Sarana dan Prasarana}

Dalam mendukung keberadaannya sebagai kawasan pariwisata belanja, sarana merupakan fasilitas pendukung dan penunjang yang sangat penting dalam mendukung keberadaan fungsi kawasan. Dalam hal ini keberadaan home industry MEP belum difasilitasi dengan komponen pendukung yang dibutuhkan oleh pengunjung seperti lahan parkir, tempat beribadah, akses komunikasi dan informasi, pelayanan produk perbankan, fasilitas kebersihan dll. Pada kawasan hunian sekitar usaha berbasis rumah tangga MEP, terdapat sarana pendidikan dan peribadatan yang sudah baik dan memadai dengan tampilan atau visualisasi yang layak. Hal tersebut dapat dilihat pada gambar 5 berikut:
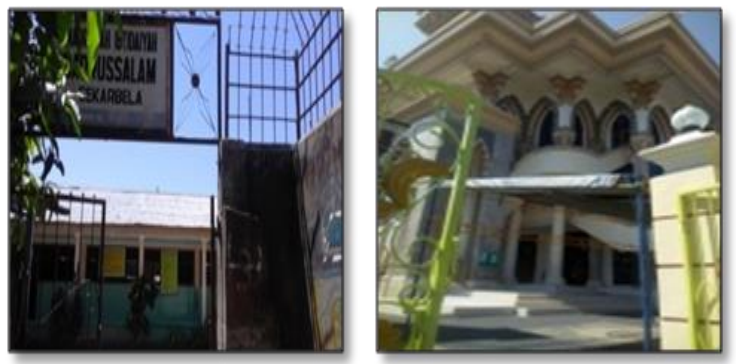

Gambar 5. Kondisi sarana pendidikan dan peribadatan

Sementara itu, untuk jaringan prasarana jalan, dengan kondisi yang sudah cukup baik dan memadai. Adapun kondisi jalan yang ada berupa gang-gang yang ada di masing-masing lingkungan yang sebagian besar jalan lingkungan dan gang-gangnya sudah menggunakan beton. Namun masih terdapat pula jalan setapak yaitu jalan tanah. Hal tersebut dapat dilihat pada gambar 6 berikut:
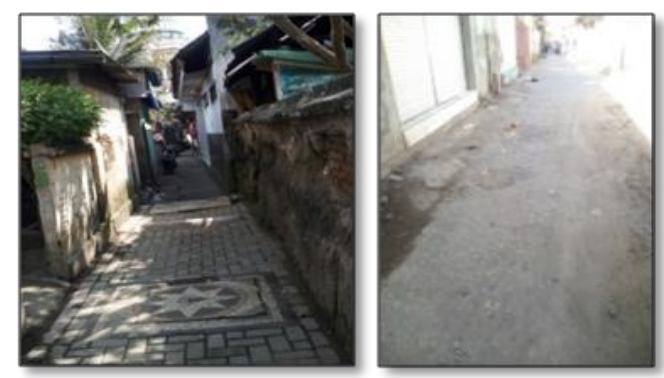

Gambar 6. Kondisi jaringan jalan

Untuk penggunaan air pada hunian sekitar usaha berbasis rumah tangga MEP ini sebagian besar sudah menggunakan sumur bor/pompa dan juga sudah menggunakan jasa PDAM. Kondisinya terlihat baik dan persebaran airnya terbilang merata. Namun, karena kondisi yang terlihat kumuh serta lokasi keran air yang terbilang kotor menyebabkan kualitas air kurang higienis dalam proses pemenuhannya sebagai air minum dan air bersih serta belum diperhatikan adalah tidak adanya aliran limpasan air sehingga air mengalir dan membasahi 
lahan dan jalan yang tidak bisa menyerap air yang akhirnya akan menimbulkan genangan. Hal tersebut dapat dilihat pada gambar 7 berikut:

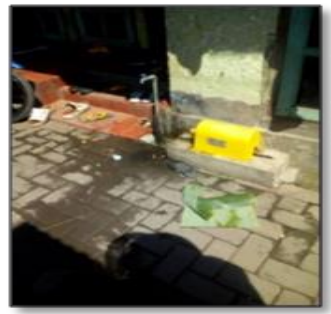

Gambar 7. Kondisi jaringan air bersih

Kondisi jaringan drainase saat ini tidak berfungsi dengan baik karena banyak sampah yang dibuang ke aliran drainse serta adanya pembuangan limbah rumah tangga yang langsung dibuang ke aliran drainase yang menyebabkan kondisi air drainase menjadi kotor dan pekat. Hal tersebut dapat dilihat pada gambar 8 berikut:

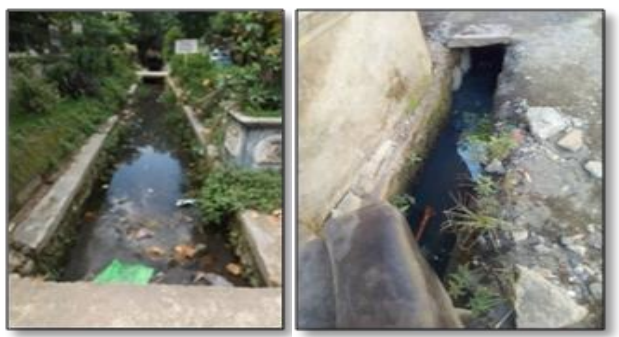

Gambar 8. Kondisi jaringan drainase

Kondisi jaringan limbah, berdasarkan hasil dari wawancara, limbah yang berupa kayu-kayu hasil pembakaran dalam proses pembuatan perhiasan dimanfaatkan kembali sebagai arang oleh masyarakat. Sedangkan untuk limbah domestik (limbah rumah tangga) langsung dibuang ke saluran drainase dan sungai. Hal tersebut dapat dilihat pada gambar 9 berikut:

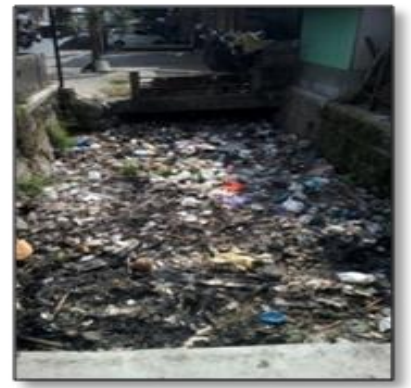

Gambar 9. Kondisi jaringan limbah

Kondisi jaringan persampahan, masih banyaknya sampah yang berserakan di sekitar rumah masyarakat. Selain itu, kebiasaan masyarakat yang membuang sampah di lahan kosong dan sungai pun masih menjadi pemandangan yang dapat dilihat sehari-hari sehingga tidak heran kalau kondisi sungai dan lahan kosong yang ada pada wilayah penelitian sangat kotor dan dipenuhi dengan sampah. Hal tersebut dapat dilihat pada gambar 10 berikut:
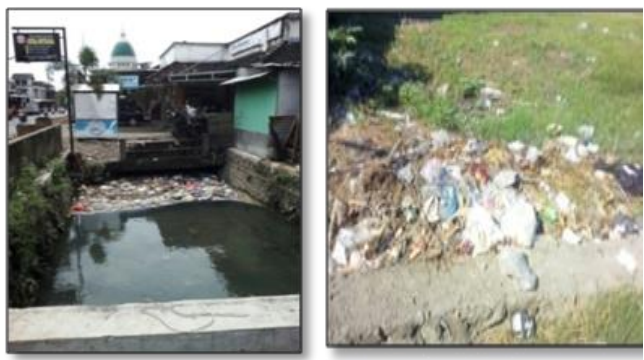

Gambar 10. Kondisi jaringan persampahan

\section{c. Karakteristik Lingkungan}

Adanya kawasan usaha berbasis rumah tangga MEP di Kelurahan Karang Pule, Kecamatan Sekarbela, Kota Mataram memberikan dampak kepada lingkungan yang ada disekitarnya. Dampak tersebut berupa bertambahnya lahan kritis yang diakibatkan karena pembangunan tempat pembuatan serta toko emas tersebut. Dengan adanya pembangunan tersebut menyebabkan sering terjadinya bencana banjir yang melanda Kelurahan Karang Pule, Kecamatan Sekarbela, Kota Mataram karena minimnya daerah resapan air dan saluran drainase yang tidak berjalan sesuai dengan fungsinya.

Munculnya permukiman kumuh juga menjadi salah satu masalah pada kawasan hunian sekitar usaha berbasis rumah tangga MEP. Selain itu, terjadinya pencemaran tanah dan air sebagai akibat dari pembuangan limbah emas yang menggunakan raksa (Merkuri/Hg) untuk memisahkan emas dengan pasir atau tanah hasil penggalian. Bahan raksa yang digunakan tersebut tergolong berbahaya dan beracun sehingga sangat berbahaya sekali jika air yang sudah tercemar tersebut sampai di konsumsi oleh manusia.

Pencemaran tanah dan air juga disebabakan oleh tumpahan-tumpahan minyak atau oli pada saat penggilingan batu emas. Selain itu, adanya penyimpangan-penyimpangan terkait dengan pendirian bangunan yang berada di sempadan sungai juga masih menjadi masalah lingkungan yang tidak dapat dihindari.

\section{Karakteristik Non Fisik}

Karakteristik non fisik diidentifikasi dengan melihat karakteristik masyarakat serta aktivitas yang berlangsung di dalamnya.

a. Karakteristik Masyarakat

Secara umum, berdasarkan wawancara yang telah dilakukan, diketahui bahwa masyarakat pada 
kawasan permukiman dengan usaha berbasis rumah tangga MEP memiliki latar belakang pendidikan yang masih rendah. Adanya latar belakang pendidikan yang rendah ini dapat diketahui dari sebagian besar masyarakat yang pendidikannya hanya sebatas lulusan atau tamatan Sekolah Menengah Atas (SMA) dan hanya sebagian kecil masyarakat yang lulusan sarjana. Masyarakat yang ada pada kawasan wisata belanja MEP ini cenderung memiliki sistem kekerabatan sehingga tenaga kerja dari kegiatan usaha berbasis rumah tangga Mutiara, Emas dan Perak (MEP) ini sebagian besar merupakan anggota keluarga sendiri yang dijadikan sebagai karyawannya sehingga secara tidak langsung mempersempit peluang dan ksempatan kerja masyarakat luas.

Masyarakat yang berada pada hunian sekitar usaha berbasis rumah tangga MEP merupakan masyarakat yang tidak bekerja dalam sektor industri MEP seperti halnya masyarakat yang bekerja sebagai petani, nelayan, pengawai pemerintah, buruh dan lain-lain. Tingkat pendidikan masyarakat sekitar dapat diketahui dari hunian yang ditempati. Masyarakat yang memiliki hunian yang layak cenderung memiliki tingkat pendidikan yang tinggi dan sebaliknya. Jenis pekerjaan yang dimiliki masyarakat pun dapat dilihat dari bentuk dan kualitas hunian yang ditempati oleh masyarakat. Masyarakat yang memiliki hunian yang layak cenderung memiliki pekerjaan yang layak juga disertai dengan jumlah pendapatan yang tinggi dan begitupun sebaliknya.

\section{b. Aktivitas Masyarakat}

Hunian sekitar usaha berbasis rumah tangga ini dalam hal penggunaan ruangnya hanya dijadikan sebagai tempat tinggal atau hunian. Penggunaan ruang sepenuhnya hanya digunakan sebagai tempat tinggal dalam pemenuhan kebutuhan keluarga tanpa adanya pencampuran kegiatan lainnya sehingga hanya berfokus kepada kepentingan dan urusan keluarga semata.

Berdasarkan penggunan ruang pada kegiatan usaha berbasis rumah tangga MEP, masyarakat memanfaatkan rumah tempat tinggal atau hunian sebagai tempat usaha (rumah produktif). Penggunaan ruang terbagi menjadi 3 (tiga), yaitu: 1) hunian dan workshop pengrajin, 2) hunian dan toko penjual, dan 3) hunian, workshop dan toko.

\section{Analisis SWOT Permukiman dengan Potensi Usaha Berbasis Rumah Tangga}

Analisis SWOT dilakukan dengan tahapan mengkaji faktor internal dan eksternal sebagaimana dapat dilihat pada tabel 1. Selanjutnya dilakukan perhitungan hasil faktor internal dan eksternal sebagaimana dapat dilihat pada tabel 2 dan 3 hingga mendapatkan hasil skoring pada tabel 4. Hasil skoring dapat terlihat juga pada gambar 11 yang menunjukkan pemetaan nilai kuadran sehingga dapat diketahui posisi dan strategi pengembangan dari potensi usaha berbasis rumah tangga MEP dan hunian sekitarnya di kelurahan Karang Pule, kecamatan Sekarbela, kota Mataram.

Tabel 1. Faktor-Faktor Internal dan Eksternal

\begin{tabular}{|c|c|}
\hline Internal & Eksternal \\
\hline $\begin{array}{l}\text { Kekuatan (strengths) } \\
\text { a. Masyarakat (pengrajin) } \\
\text { memiliki kreativitas dan } \\
\text { kemampuan yang tinggi } \\
\text { dalam membuat produk } \\
\text { perhiasan dengan } \\
\text { berbagai bentuk yang } \\
\text { menarik } \\
\text { b. Tempat dan hunian usaha } \\
\text { berbasis rumah tangga } \\
\text { MEP yang sudah layak } \\
\text { dan memiliki kulitas } \\
\text { visual yang baik } \\
\text { c. Terdapat akses jalan dan } \\
\text { infrastruktur pendukung } \\
\text { serta jaringan pemasaran } \\
\text { yang cukup luas } \\
\text { d. Temasuk kedalam } \\
\text { wilayah dengan } \\
\text { lingkungan yang aman } \\
\text { dan minim kasus kriminal }\end{array}$ & $\begin{array}{l}\text { Peluang (opportunities) } \\
\text { a. Terdapat pengerajin } \\
\text { yang memiliki potensi } \\
\text { mengembangkan } \\
\text { desain dari produk } \\
\text { kerajinan MEP } \\
\text { b. Telah ditetapkan } \\
\text { sebagai kawasan } \\
\text { pariwisata belanja } \\
\text { c. Terjadi perbaikan } \\
\text { terhadap sarana dan } \\
\text { prasarana yang } \\
\text { semakin membaik } \\
\text { d. Merupakan satu- } \\
\text { satunya industri } \\
\text { Mutiara, Emas dan } \\
\text { Perak (MEP) di Kota } \\
\text { Mataram }\end{array}$ \\
\hline $\begin{array}{l}\text { Kelemahan (weakness) } \\
\text { a. Masyarakat yang } \\
\text { menganut sistem } \\
\text { kekrabatan sehingga yang } \\
\text { bekerja dalam sektor } \\
\text { industri ini hanya anggota } \\
\text { keluarga } \\
\text { b. Hunian dengan kegiatan } \\
\text { usaha berbasis rumah } \\
\text { tangga MEP masih } \\
\text { bercampur dengan } \\
\text { aktivitas lainnya } \\
\text { c. Rendahnya pengadaan } \\
\text { dan kualitas sarana dan } \\
\text { prasarana pendukung } \\
\text { baik untuk kegiatan } \\
\text { produksi sebagai } \\
\text { kawasan wisata belanja. } \\
\text { d. Kenyamanan kawasan } \\
\text { terutama di pusat } \\
\text { perbelanjaan masih } \\
\text { kurang terutama } \\
\text { mengenai masalah } \\
\text { estetika }\end{array}$ & $\begin{array}{l}\text { Ancaman (threaths) } \\
\text { a. Tingkat pendidikan } \\
\text { masyarakat } \\
\text { (pengrajin) yang } \\
\text { masih rendah } \\
\text { b. Lokasi industri yang } \\
\text { berada di tengah- } \\
\text { tengah permukiman } \\
\text { dan hunian } \\
\text { masyarakat yang tidak } \\
\text { layak } \\
\text { c. Sarana dan prasarana } \\
\text { pendukung kawasan } \\
\text { yang tidak memadai } \\
\text { d. Lingkungan sekitar } \\
\text { lokasi industri yang } \\
\text { tidak memadai dan } \\
\text { kotor }\end{array}$ \\
\hline
\end{tabular}

Tabel 2. Hasil Internal Factor Analisis Summary (IFAS)

\begin{tabular}{|c|c|c|c|}
\hline Faktor Internal & Bobot & Rating & $\mathrm{B} \times \mathrm{R}$ \\
\hline $\begin{array}{ll}\text { I. } & \text { Kekuatan (strenghts) }\end{array}$ & & & \\
\hline $\begin{array}{l}\text { a. Masyarakat (pengrajin) } \\
\text { memiliki kreativitas } \\
\text { dan kemampuan yang } \\
\text { tinggi dalam membuat } \\
\text { produk perhiasan } \\
\text { dengan berbagai }\end{array}$ & 0,17 & 3 & 0,51 \\
\hline
\end{tabular}


bentuk yang menarik

b. Hunian dengan usaha

$0,15 \quad 2 \quad 0,3$ berbasis rumah tangga MEP yang sudah layak dan memiliki visual yang baik

c. Terdapat akses jalan dan infrastruktur pendukung serta jaringan pemasaran yang cukup luas

d. Temasuk kedalam wilayah dengan lingkungan yang aman dan minim dalam kasus kriminal

\begin{tabular}{|c|c|c|c|c|}
\hline \multirow{2}{*}{\multicolumn{2}{|c|}{$\begin{array}{l}\text { Sub Total } \\
\text { II. Kelemahan (weakness) }\end{array}$}} & 0,55 & 8 & 1,18 \\
\hline & & & & \\
\hline \multicolumn{2}{|c|}{$\begin{array}{ll}\text { a. } & \text { Masyarakat yang } \\
\text { menganut sistem } \\
\text { kekrabatan sehingga } \\
\text { yang bekerja dalam } \\
\text { sektor industri ini } \\
\text { hanya anggota keluarga }\end{array}$} & 0,05 & -1 & $-0,05$ \\
\hline \multicolumn{2}{|c|}{$\begin{array}{l}\text { b. Hunian dengan usaha } \\
\text { berbasis rumah tangga } \\
\text { MEP masih bercampur } \\
\text { dengan aktivitas } \\
\text { lainnya }\end{array}$} & 0,12 & -2 & $-0,24$ \\
\hline \multicolumn{2}{|c|}{$\begin{array}{l}\text { c. Rendahnya pengadaan } \\
\text { dan kualitas sarana dan } \\
\text { prasarana pendukung } \\
\text { baik untuk kegiatan } \\
\text { produksi sebagai } \\
\text { kawasan wisata belanja }\end{array}$} & 0,13 & -2 & $-0,26$ \\
\hline \multicolumn{2}{|c|}{$\begin{array}{ll}\text { d. } & \text { Kenyamanan kawasan } \\
\text { terutama di pusat } \\
\text { perbelanjaan masih } \\
\text { kurang terutama } \\
\text { mengenai masalah } \\
\text { estetika } \\
\end{array}$} & 0,15 & -2 & $-0,3$ \\
\hline \multicolumn{2}{|c|}{ Sun Total } & 0,45 & -7 & $-0,85$ \\
\hline \multicolumn{2}{|c|}{ Total $(I+I I)$} & 1,00 & 1 & 0,33 \\
\hline \multirow{2}{*}{\multicolumn{2}{|c|}{$\begin{array}{l}\text { Kekuatan (strenghts) } \\
\text { Kelemahan (weakness) }\end{array}$}} & $4=2$ & & \\
\hline & & & & \\
\hline
\end{tabular}

Faktor kekuatan (strenghts) mempunyai nilai bobot sebesar 0,55 dengan total rating diperoleh sebesar 2 dan kelemahan (weakness) mempunyai nilai bobot sebesar 0,45 dengan total rating -1,75. Dari nilai tersebut dapat diartikan bahwa usaha berbasis rumah tangga MEP dan hunian sekitarnya di Kelurahan Karang Pule, Kecamatan Sekarbela, Kota Mataram memiliki kekuatan lebih besar dibandingkan dengan nilai kelemahan. Hal ini menunjukkan bahwa usaha berbasis rumah tangga MEP ini memilki potensi sumber daya yang mendukung eksistensi kawasan pariwisata belanja. Berdasarkan hasil perhitungan dari nilai rating faktor lingkungan internal dalam potensi usaha berbasis rumah tangga MEP dan hunian sekitarnya, yaitu faktor kekuatan (strenght) dikurangi dengan faktor kelemahan (weakness) diperoleh nilai $X$ sebagai sumbu horizontal yaitu 0,25 , dengan demikian, nilai sumbu $\mathrm{X}$ dalam diagram SWOT adalah sebesar 0,25.

Tabel 3. Hasil External Faktor Analisis Summary (EFAS) \begin{tabular}{|l|l|l|l|}
\hline Faktor Internal & Bobot & Rating & B x R \\
\hline
\end{tabular}

\begin{tabular}{ccccc} 
I. & Peluang (opportunities) & & & \\
\hline a. & Terdapat pengerajin & 0,07 & 1 & 0,07
\end{tabular}

yang memiliki

potensi

mengembangkan

desain dari produk

kerajinan MEP

b. Telah ditetapkan sebagai kawasan pariwisata belanja

$0,15 \quad 2 \quad 0,3$

c. Terjadi perbaikan

$0,06 \quad 1 \quad 0,06$

terhadap sarana dan prasarana yang semakin membaik

d. Merupakan satusatunya industri MEP di Kota Mataram

\begin{tabular}{|c|c|c|c|c|}
\hline \multicolumn{2}{|c|}{ Sub Total } & 0,43 & 6 & 0,73 \\
\hline \multicolumn{5}{|c|}{ II. Ancaman (threaths) } \\
\hline a. & $\begin{array}{l}\text { Tingkat pendidikan } \\
\text { masyarakat } \\
\text { (pengrajin) yang } \\
\text { masih rendah }\end{array}$ & 0,08 & -1 & $-0,08$ \\
\hline 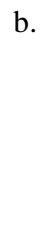 & $\begin{array}{l}\text { Lokasi industri yang } \\
\text { berada di tengah- } \\
\text { tengah permukiman } \\
\text { dan hunian } \\
\text { masyarakat yang } \\
\text { tidak layak }\end{array}$ & 0,12 & -2 & $-0,24$ \\
\hline c. & $\begin{array}{l}\text { Sarana dan prasarana } \\
\text { pendukung kawasan } \\
\text { yang tidak memadai }\end{array}$ & 0,17 & -2 & $-0,34$ \\
\hline d. & $\begin{array}{l}\text { Lingkungan sekitar } \\
\text { lokasi industri yang } \\
\text { tidak memadai dan } \\
\text { kotor }\end{array}$ & 0,20 & -3 & $-0,60$ \\
\hline & Total & 0,57 & -8 & $-1,26$ \\
\hline & al (I+II) & 1,00 & -2 & $-0,53$ \\
\hline
\end{tabular}

Peluang (Opportunity) : 6/4 =1,5

Ancaman (Threaths) : $-8 / 4=-2$

Faktor peluang (opportunity) mempunyai nilai bobot sebesar 0,43 dengan total rating 1,5 dan ancaman (threaths) mempunyai nilai bobot 0,57 dengan total rating -2. Dari nilai tersebut dapat diartikan bahwa usaha berbasis rumah tangga MEP dan hunian sekitarnya memiliki nilai ancaman lebih besar dibandingkan nilai peluang. Berdasarkan hasil perhitungan dari nilai rating faktor lingkungan eksternal dalam potensi usaha berbasis rumah tangga MEP dan hunian sekitarnya, yaitu faktor peluang (opportunity) dikurangi dengan faktor ancaman (treaths) diperoleh nilai $\mathrm{Y}$ sebagai sumbu vertikal yaitu 0,25 , dengan demikian, nilai sumbu $\mathrm{X}$ dalam diagram SWOT adalah sebesar -0,5. 
Tabel 4. Hasil Skoring

\begin{tabular}{lcc}
\hline \multicolumn{1}{c}{ Kriteria } & Koordinat & Keterangan \\
\hline Faktor Internal & & \\
\hline $\begin{array}{l}\text { Kekuatan } \\
\text { Kelemahan }\end{array}$ & 0,25 & $\mathrm{X}$ \\
\hline Faktor Eksternal & & \\
\hline $\begin{array}{l}\text { Peluang } \\
\text { Ancaman }\end{array}$ & $-0,5$ & $\mathrm{Y}$ \\
\hline
\end{tabular}

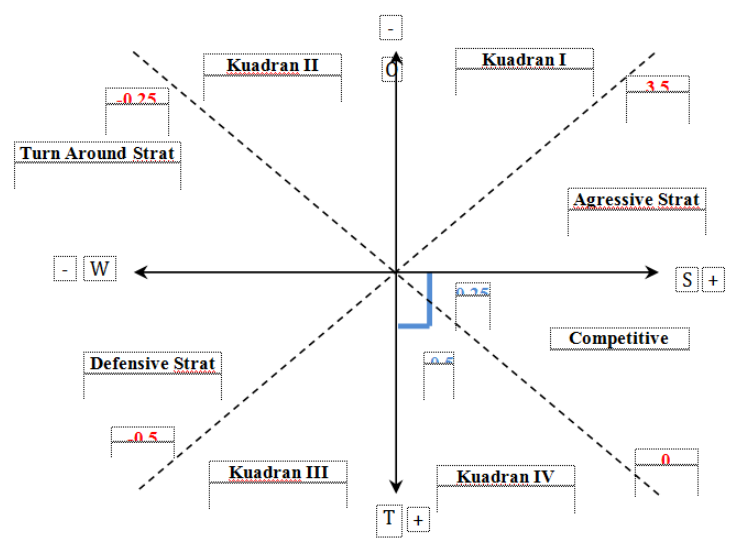

Gambar 11. Pemetaan Nilai Kuadran

Berdasarkan pemetaan nilai kuadran dapat diketahui bahwa posisi potensi usaha berbasis rumah tangga MEP dan hunian sekitarnya yang ada di Kelurahan Karang Pule, Kecamatan Sekarbela, Kota Mataram berada di Kuadran IV dengan koordinat $(-0,25,-0,5)$. Kuadran IV ini merupakan kuadran dibatasi oleh sumbu $\mathrm{X}$ yang positif dan sumbu $\mathrm{Y}$ yang negatif. Strategi usaha yang tersedia adalah strategi berdaya saing atau Competitive Strategic.

Meskipun kawasan menghadapi ancaman dari eksternal tetapi di sisi lain kawasan mempunyai kekuatan. Bila manajemen mampu mengoptimalkan kekuatan yang dimiliki serta meminimalkan kelemahan internal, maka ancaman yang usaha akan bisa diatasi, sehingga kawasan bisa melakukan diversifikasi usaha, mengembangkan pasar dan peningkatan kualitas visual atau citra kawasan. Kuadran ini menggambarkan kondisi intern yang kuat dan lingkungan yang kuat mendukung sehingga arah, sasaran dan strategi organisasi yang sesuai adalah berorientasi ke luar, yaitu:

1. Peningkatan kualitas visual atau citra kawasan yang lebih baik sehingga memiliki daya tarik yang berdaya saing dengan kawasan wisata lainnya.

2. Diversifikasi dalam bentuk kolaborasi usaha MEP dengan potensi usaha lainnya yang berada di sekitarnya, seperti kuliner atau wisata religi serta usaha di luar kawasan, seperti travel, hotel atau penginapan, restaurant dan tempat wisata lainnya yang mendukung,

3. Mengembangkan pasar melalui pemanfaatan sistem informasi dan teknologi yang mulai meluas saat ini dengan strategi pemasaran yang tepat, baik secara langsung atau melalui online.

\section{Kesimpulan}

Berdasarkan penelitian yang telah dilakukan, maka dapat disimpulkan bahwa:

1. Karakteristik permukiman dengan potensi usaha berbasis rumah tangga MEP dan hunian sekitarnya dibentuk oleh karakter fisik dan non fisik yang berada di kawasan tersebut.

2. Karakteristik fisik yang terdiri dari tata bangunan, sarana dan prasarana serta lingkungan menjadi representasi kawasan secara visual. Keberadaan fasilitas yang minim dan lingkungan yang kurang mendukung tentunya juga menjadi perhatian dalam upaya peningkatan kualtas visual kawasan pariwisata belanja. Kualitas visual yang baik dan mendukung keberadaan permukiman dengan potensi usaha berbasis rumah tangga kekuatan karakteristik kawasan yang kuat.

3. Karakteristik non fisik berdasarkan kondisi masyarakat menunjukkan bahwa masyarakat menganut sistem kekerabatan dan nilai lokal setempat dengan aktivitas masyarakat, ada yang menggunakan rumah tinggalnya sebagai hunian saja dan ada yang menggunakannya sekaligus sebagai usaha berbasis rumah tangga yang terbagi menjadi 1) hunian dan workshop pengrajin, 2) hunian dan toko penjual, dan 3) pemanfaatan ruang sebagai hunian, workshop dan toko.

4. Hasil analisis SWOT dengan IFAS EFAS menunjukkan posisi permukiman dengan potensi usaha berbasis rumah tangga memerlukan strategi kompetitif sehingga diperlukan upaya pengembangan yang tepat dengan peningkatan kualitas visual atau citra kawasan, diversifikasi usaha dalam bentuk kolaborasi usaha MEP dengan potensi usaha lainnya yang berada di sekitarnya atau di luar kawasan dan mengembangkan pasar melalui pemanfaatan sistem informasi dan teknologi dengan strategi pemasaran yang tepat.

\section{Saran}

Berdasarkan penelitian tersebut, maka disarankan beberapa hal sebagai berikut:

1. Penelitian lanjutan terkait dengan perkembangan wilayah sebagai kawasan wisata belanja Mutiara, Emas dan Perak (MEP) sehingga dapat memberikan informasi yang jelas dan tepat terhadap wisatawan yang ingin berkunjung ke kawasan wisata belanja MEP tersebut.

2. Perlunya dukungan dan kerjasama antara pemerintah daerah, stakeholder, masyarakat atau 
komunitas terkait dengan pengembangan usaha berbasis rumah sehingga potensi yang dimiliki dapat terus lestari dan meningkatkan kualitas perekonomian masyarakat

3. Penataan permukiman dengan usaha berbasis rumah tangga yang lebih baik sehingga dapat meningkatkan kualitas visual

4. Melibatkan dan memberikan pemahaman kepada masyarakat dan semua pihak yang terkait tentang pentingnya pemukiman dan hunian yang layak dan berkelanjutan.

\section{Daftar Pustaka}

Doxiadis, C.A. (1968). An Introduction to The Science of Human Settlements. London: Hutchinson Of London.

Doxiadis, C.A. (1974). Action for A Better Scientific Approach to The Subject of Human Settlements. The Journal of Ekistics, Volume 38 No. 229 Desember 1974

Hudson. (1970). Struktur Tata Ruang Kota, Pustaka Pelajar, Yogyakarta.

Peraturan Daerah No. 12 Tahun 2011 tentang Rencana Tata Ruang Wilayah (RTRW) Kota Mataram tahun $2011-2031$

Siahaan. (1996). Pola Pengembangan Industri. Jakarta: Departemen Perindustrian

Silas, J. (1993). Pemukiman Kumuh di Jakarta Tinjauan Kontradiktif-Komparatif Masyarakat. Jurnal Sosiologi. 2, 1-9.

Sugiyono. 2014. Metode Penelitian Pendidikan Pendekatan Kuantitatif, Kualitatif Dan $R \& D$. Bandung: Alfabeta.

Sushanti, I.R. (2015). Pengaruh Keberadaan Industri terhadap Perumahan dan Kawasan Permukiman di Kota Mataram. Jurnal Sosial Ekonomi Humaniora. Universitas Mataram, Vol.1 No.1.

Sushanti, I.R. dan Fitri, I.S. (2017). Implications of Pearl, Gold, Silver (PGS) Craft Industrial Cluster Towards Settlements Region Karang Pule Village, Sekarbela District Of Mataram City. IOP Conference Series: Earth and Environmental Science Vol 70 (2017). 012039 https://iopscience.iop.org/journal/1755$\underline{1315}$

Tipple, A.G., dan Kellet, P. (2002), Homebased Enterprises and Housing Policy: Empirical Evidence from India and Indonesia. Prosiding ENHR in Viena. 